\title{
Dekolonisasi Arsip Sebagai Warisan Budaya: Kajian Awal Pengembalian Arsip Statis Era Hindia-Belanda
}

\section{$\begin{array}{lllllllll} & \text { I } & \mathbf{N} & \mathbf{T} & \mathbf{I} & \mathbf{S} & \mathbf{A} & \mathbf{R} & \mathbf{I}\end{array}$}

Dekolonisasi dapat terjadi di segala bidang, termasuk juga bidang kearsipan. Konvensi Wina tahun 1983 telah menggariskan bahwa arsip yang tercipta di negara asal (negara jajahan) akan menjadi milik negara tersebut ketika negara itu merdeka. Dekolonisasi arsip sudah banyak terjadi, contohnya di negara-negara jajahan Inggris dan Prancis. Di Indonesia sendiri, dekolonisasi arsip terjadi ketika kerja sama dilakukan pada tahun 1970-an untuk mengembalikan arsip Djogdja Documenten dari Belanda. Penelitian ini akan menginvestigasi literatur-literatur terkait dekolonisasi pada umumnya, dan dekolonisasi arsip pada khususnya. Lebih jauh lagi, penelitian ini akan membahas kajian awal dekolonisasi arsip era Hindia-Belanda, baik di lingkungan analog maupun di lingkungan digital. Metode yang digunakan dalam penelitian ini adalah deskriptif analitis dengan menganalisis bahan pustaka, literatur mengenai dekolonisasi arsip, dan laporanlaporan terkait kerja sama pengembalian arsip. Hasil penelitian menunjukkan bahwa sudah ada dekolonisasi arsip terjadi di dua lingkungan tersebut.

\section{$\begin{array}{lllllllll}A & B & S & T & R & A & C & T\end{array}$}

Decolonization can occur in various fields, including the archival field. Vienna Convention 1983 has stated that "State archives of the predecessor State" means all documents of whatever date and kind, produced or received by the predecessor State in the exercise of its functions which, at the date of the succession of States, belonged to the predecessor State according to its internal law and were preserved by it directly or under its control as archives for whatever purpose. Decolonization in archival fields has occurred in some countries, such as England and France. In Indonesia, archival decolonization occurred in 1970s when the cooperation to bring back Djogdja Documents occurred. Furthermore, this research uses descriptive analytics methods by investigating books, reports, and other sources about archival decolonization both in conventional and digital environment. The results show that there is archival decolonization in those both areas.
PENULIS

Jajang Nurjaman

Arsip Nasional Republik Indonesia jajang.nurjaman@umail.leidenuniv.nl

\section{KATA KUNCI}

arsip statis, dekolonisasi, Hindia-Belanda

\section{KEY WORDS}

archives, decolonization, Dutch East Indies 


\section{PENGANTAR}

\section{Latar Belakang Masalah}

Beberapa waktu lalu pada bulan Maret tahun 2020, masyarakat Indonesia dihebohkan dengan pengembalian keris yang ditengarai milik Pangeran Diponegoro. Keris tersebut dikembalikan ke Indonesia setelah "mendekam" 189 tahun di Belanda. Keris tersebut adalah Keris Nogo Siluman, yang pada tahun 1831 dibawa oleh Kolonel Jan-Baptist Cleerens ke Belanda. Tanggal 4 Maret 2020, keris tersebut diserahkan kembali ke Indonesia. Keris tersebut telah lama menjadi koleksi Museum Volkenkunde di Leiden, Belanda. Perjalanan panjang untuk memulangkan keris tersebut sudah sejak tahun 1975. Kala itu, Indonesia dan Belanda membuat perjanjian untuk pengembalian benda-benda warisan budaya yang berkaitan dengan tokoh bersejarah. Pada tahun berikutnya, Belanda mulai memulangkan beberapa benda bersejarah seperti arca dan bendabenda jarahan dari Perang Lombok. Pada tahun 2015, Belanda kembali melakukan pengembalian benda bersejarah, yaitu milik Pangeran Diponegoro, antara lain tombak dan pelana kudanya. Benda-benda terkait Pangeran Diponegoro yang dikembalikan ini sempat dipamerkan di Galeri Nasional, Jakarta. Proses pengembalian benda-benda bersejarah ini disebut juga dekolonisasi pada warisan budaya. Dekolonisasi ini sudah terjadi pada benda warisan budaya sewaktu Belanda mendirikan sebuah pemerintahan di wilayah Indonesia. Namun, dekolonisasi terhadap arsip sampai saat ini masih belum terdengar atau bisa dikatakan masih dilakukan dalam skala yang tidak besar.

Arsip dikategorikan sebagai salah satu jenis warisan budaya. Bahkan, arsip sudah masuk dalam memory of the world register, suatu daftar warisan budaya dunia yang telah diakui oleh the United Nations of Educational, Scientific, and Culural Organization (UNESCO). Dalam daftar tersebut, tercatat ada delapan dokumen dari Indonesia yang dikategorikan sebagai warisan budaya dunia, dan empat di antaranya adalah arsip, yaitu Arsip Perusahaan Dagang Belanda di Hindia Timur (VOC), Arsip Konferensi Asia Afrika (KAA), Arsip Tsunami Aceh 2004, dan Arsip Pemugaran Candi Borobudur. Sebagai benda yang sudah diakui menjadi warisan budaya, maka arsip yang dulunya sempat direbut oleh Belanda ataupun negara pengkoloni lainnya sudah selayaknya didekolonisasi.

Indonesia, sebagai salah satu bekas jajahan Belanda, banyak mewarisi juga arsip yang diciptakan pada era HindiaBelanda. Arsip-arsip tersebut bernilai sejarah dan menjadi arsip statis dan kemudian disimpan di lembaga kearsipan nasional, yaitu Arsip Nasional Republik Indonesia (ANRI). Tercatat lebih dari 10 
kilometer arsip periode Hindia-Belanda yang disimpan di ANRI. Khazanah arsip yang disimpan tersebut, memang "diwariskan" oleh pemerintah kolonial Hindia-Belanda ketika landsarchief atau arsip nasional ketika itu berdiri. Namun, tidak semua arsip yang ada pada periode tersebut lengkap. Ada beberapa khazanah yang memang dibawa oleh pihak Belanda ketika mereka angkat kaki dari bumi Indonesia. Arsip-arsip inilah yang bisa melengkapi khazanah arsip yang sudah ada.

Usaha-usaha untuk memulangkan arsip yang dibawa pada masa kolonisasi setidaknya sudah dilakukan sejak tahun 1960-an. Usaha ini tercatat ketika arsiparis Indonesia pada era tersebut memohon kepada Belanda untuk memulangkan arsip yang dinamakan Djogdja Documenten. Penjajakan kerja sama tersebut berhasil ketika pada tahun 1970-an hingga 1990an, arsip tersebut dapat dipulangkan dan kini disimpan di ANRI dengan nama khazanah yang sama. Tercatat ada 356 nomor arsip Djogdja Documenten yang disimpan di ANRI. Dari kasus ini, apakah mungkin ada lagi arsip yang memang diciptakan di Indonesia (Hindia-Belanda) yang masih disimpan di Belanda? Penelitian ini akan mengkaji lebih dalam mengenai khazanah arsip yang mungkin dapat didekolonisasi dari Belanda. Lebih jauh lagi, penelitian ini akan menjelaskan konsep-konsep dan teori dekolonisasi yang dikaitkan dengan ilmu kearsipan. Selanjutnya, kemungkinan-kemungkinan atau cara-cara untuk mendekolonisasi arsip pada era digital juga akan dibahas dalam penelitian ini.

\section{Rumusan Masalah}

Tema besar dari penelitian ini adalah dekolonisasi dan kaitannya dengan ilmu kearsipan. Adapun tema yang lebih khusus lagi adalah kajian awal dekolonisasi arsip periode HindiaBelanda. Alasan penulis memilih periode Hindia-Belanda dalam penelitian ini adalah karena pada era inilah dimulai adanya sebuah pemerintahan kolonial di Indonesia. Dari latar belakang masalah mengenai dekolonisasi warisan budaya yang masih sedikit mengenai arsip, maka penulis merumuskan masalah-masalah dalam penelitian ini sebagai berikut:

1. Bagaimanakah konsep dekolonisasi dikaitkan dengan ilmu kearsipan?

1.1. B aga imana konsep dekolonisasi arsip dikaitkan dengan era digital?

2. Kemungkinan-kemungkinan apa yang bisa terjadi jika dekolonisasi dilakukan pada arsip periode Hindia-Belanda?

2.1. Khazanah arsip apa saja yang bisa didekolonisasi?

2.2. Apakah mungkin dekolonisasi arsip periode Hindia-Belanda dilakukan di lingkungan 
digital?

\section{Tujuan Penelitian}

Tujuan dari penelitian ini adalah menganalisis konsep dekolonisasi secara umum, yang kemudian dikaitkan dengan konsep dekolonisasi arsip. Penelitian dilakukan dengan menginvestigasi literatur serta laporan-laporan yang ada, dan studi kasus pada dekolonisasi warisan budaya, baik itu benda bersejarah maupun arsip. Maka, secara ringkas penelitian ini dimaksudkan untuk:

1. Menjabarkan dan menganalisis konsep dekolonisasi dan kaitannya dengan ilmu kearsipan. Konsep dekolonisasi arsip pada era digital juga akan dianalisis.

2. Menjabarkan dan menganalisis k e m ung k in a n-k e m ung k in a n dekolonisasi arsip periode HindiaBelanda, baik yang sudah dan pernah terjadi maupun yang bisa dilakukan pada masa depan. Analisis ini akan menyentuh juga kemungkinan dekolonisasi arsip Hindia-Belanda pada era digital.

\section{Metodologi Penelitian}

Untuk menjawab masalah penelitian, penulis menggunakan metode deskriptif analitis. Penelitian akan berfokus pada studi literatur yang sudah ada mengenai dekolonisasi, arsip, dan dekolonisasi arsip. Selain dari literatur, penulis juga menggunakan laporan tertulis yang dijadikan dasar untuk melihat kasuskasus dekolonisasi arsip sebelumnya.

Pertama, penulis melakukan studi literatur yang terkait dengan dekolonisasi. Studi literatur ini akan menganalisis terkait dekolonisasi yang dilakukan terhadap arsip. Setelah studi literatur, penulis melakukan analisis terhadap laporan tentang dekolonisasi arsip yang sudah pernah terjadi. Tahapan selanjutnya adalah mengombinasikan antara literatur yang ada dengan konteks lingkungan digital. Akhirnya, setelah melakukan analisis studi literatur penulis mendapatkan simpulan untuk menjawab pertanyaan penelitian.

\section{Kerangka Pemikiran \\ Dekolonisasi}

Ketika mendengar kata dekolonisasi, yang terlintas di dalam pikiran adalah kata kolonial. Dekolonisasi dalam Kamus Besar Bahasa Indonesia (KBBI) versi daring adalah penghapusan daerah jajahan, sedangkan menurut The Oxford English Dictionary, dekolonisasi diartikan sebagai withdrawal from its former colonies oy a clonial power; the acquisition of political or economic independence by such colonies" (Kennedy, 2016: 2). Bila dilihat dari pengertian tersebut, kata kuncinya ada pada kata withdrawal (penarikan kembali) dan acquisition (pemerolehan). 
Dekolonisasi dianggap sebagai proses yang dilakukan oleh bekas bangsa terjajah untuk keluar dari warisan struktural dan kulturalyang ditinggalkan oleh bekas bangsa penjajahnya (Mudzakir, 2015:2).

Linda Tuhimai Smith dalam bukunya Decolonizing Methodologies-. Research and Indigenous People mendefiniskan dekolonisasi sebagai:

"a process which engages with imperialism and colonialism at multiple levels. For researchers, one of those levels is concerned with having a more critical understanding of the underlying assumptions, motivations and values which inform research practices."

"Proses yang melibatkan imperialisme dan kolonialisme pada tingkatan yang berlipat. Bagi para peneliti, salah satu level tersebut berkaitan dengan memiliki pemahaman yang lebih kritis tentang asumsi, motivasi dan nilai-nilai yang mendasari praktik penelitian"(Smith, 2007: 20).

Pengertian lain dari dekolonisasi didapat dari Frantz Fanon, dalam bukunya The Wretched of the Earth, yaitu:

"Decolonization, which sets out to change the order of the world, is, obviously, a program of complete disorder. But it cannot come as a result of magical practices, nor of a natural shock, nor of a friendly understanding. Decolonization, as we know, is a historical process: that is to say it cannot be understood, it cannot become intelligible nor clear to itself except in the exact measure that we can discern the movements which give it historical form and content". (Fanon, 1963:36)

"Dekolonisasi, yang bertujuan mengubah tatanan dunia, jelas

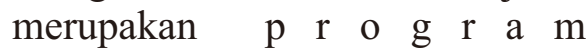
kekacauan total. Namun, itu tidak bisa datang sebagai hasil dari praktik magis, atau dari kejutan alami, atau dari pemahaman yang ramah. Dekolonisasi, seperti yang kita tahu, adalah proses historis: artinya tidak dapat dipahami, tidak dapat menjadi terang atau jelas bagi dirinya sendiri kecuali dalam ukuran yang tepat bahwa kita dapat melihat gerakan yang memberinya bentuk dan konten historis."

Dekolonisasi diartikan tidak semata-mata melulu soal transfer kekuasaaan secara historis dan politis dari negara penjajah kepada negara yang dijajah. Dari semisal negara-negara Eropa yang menjajah daerah-daerah di Asia dan Afrika, menjadi sebuah negara baru yang merdeka. Dekolonisasi memiliki arti yang lebih dalam lagi, bukan hanya sekadar menurunkan bendera penjajah dan menaikkan bendera negara baru.

Dekolonisasi tidak hanya melepaskan kontrol formal atas suatu wilayah, tetapi juga berdamai dengan hilangnya tatanan nilai kolonial yang telah menguntungkan banyak negara 
pengkoloni yang berdampak pada implikasi jangka pajang kolonialisme. Appadurai (1996: 89) berpendapat bahwa dekolonisasi adalah dialog dengan masa lalu kolonial, dan bukan sekadar pembongkaran cara-cara dan perilaku kolonial.

Dekolonisasi bisa jadi lebih dari sekadar transfer kedaulatan, dari suatu negara ke negara lainnya. Contohnya, pada kasus Iran yang secara formal tidak dijajah atau dikolonisasi. Dekolonisasi bisa berarti kebijakan pada abad XX yang bertujuan untuk mempertahankan dan memperkokoh hegemoni di Timur Tengah (Mir, 2015: 845). Lebih jauh lagi, Mir mencontohkan dekolonisasi dengan apa yang terjadi di Rusia, yaitu Revolusi Rusia:

"The timings and patterns of decolonization were extremely varied, and the goals of the movements in different countries were not always consistent with each other. Writing about the process as a whole-that is, beyond national or imperial histories-presents particular challenges. It is therefore not surprising that there is no prevailing historiographical consensus about the definition of decolonization, what precipitated it, what its effects were (and are), or whether societies-or even, for that matter, states-have achieved it"

"Pengaturan waktu dan pola dekolonisasi sangat bervariasi, dan tujuan gerakan di berbagai negara tidak selalu konsisten satu sama lain. Menulis tentang proses secara keseluruhan - yaitu, di luar sejarah nasional atau kekaisaran menyajikan tantangan khusus. Oleh karena itu, tidak mengherankan bahwa tidak ada konsensus historiografi yang berlaku tentang definisi dekolonisasi, apa yang mempercepatnya, apa dampaknya (dan apakah itu), atau apakah masyarakat - atau bahkan, dalam hal ini, negara - telah mencapainya (Mir, 2015: 845)."

Konsep dan definisi dekolonisasi akan terus berkembang sejalan dengan perkembangan politik dan sejarah dunia.

\section{Dekolonisasi Arsip}

Konferensi Wina tahun 1983 tentang Suksesi Negara Menyangkut Kekayaan, Arsip, dan Hutang, telah menyatakan di pasal 20 sebagai berikut:

Article 20

State archives

"For the purposes of the articles in the present Part, "State archives of the predecessor State" means all documents of whatever date and kind, produced or received by the predecessor State in the exercise of its functions which, at the date of the succession of States, belonged to the predecessor State according to its internal law and were preserved by it directly or under its control as archives for whatever purpose." 
Pasal 20

Arsip Negara

"Untuk keperluan pasal dalam bagian ini, "arsip negara dari negara pendahulu" berarti semua dokumen dari waktu dan jenis apa pun, yang diciptakan atau diterima oleh negara pendahulunya di pelaksanaan fungsinya yang, pada waktu suksesi negara, milik negara pendahulu sesuai dengan hukum internalnya dan dilindungi olehnya secara langsung atau di bawah kendalinya sebagai arsip untuk tujuan apapun."

Dari konvensi yang telah diratifikasi oleh Indonesia ini, dapat disimpulkan bahwa arsip yang tercipta ketika masa kolonisasi, menjadi milik Indonesia sejak negara Indonesia berdiri, yaitu tahun 1945.

Di bagian pendahuluan, penulis telah menyinggung masalah dekolonisasi warisan budaya. Arsip, dalam hal ini arsip statis, dikatakan sebagai produk kebudayaan sehingga dapat menjadi warisan budaya. Arsip sebagai benda budaya didefinisikan sebagai

"The larger 'cultural archive' - as defined by Gloria Wekker as being 'located in many things, in the way we think, do things, and look at the world, in what we find (sexually) attractive, in how our affective and rational economies are organized and intertwined. Most important, it is between our ears and in our hearts and souls' - was discussed, and the roundtable tackled 'the archive' in the rather broad, conceptual sense where everything can be an archive (Karabinos, 2019: 131).

Arsip sebagai "arsip budaya", bisa ditemukan di banyak hal, di cara kita berpikir, melakukan sesuatu, dan bagaimana kita menjalankan bisnis kita. Lebih jauh, arsip juga digunakan lebih luas di manapun kita beraktivitas .

Arsip juga didefinisikan sebagai sebuah lembaga yang melestarikan dan menyimpan arsip (sebagai benda budaya). Selain tentunya pengertian arsip menurut Undang-undang Nomor 43 tahun 2009, yaitu rekaman kegiatan atau peristiwa dalam berbagai bentuk dan media sesuai dengan perkembangan teknologi informasi dan komunikasi yang dibuat dan diterima oleh lembaga negara, pemerintahan daerah, lembaga pendidikan, perusahaan, organisasi politik, organisasi kemasyarakatan, dan perseorangan dalam pelaksanaan kehidupan bermasyarakat, berbangsa, dan bernegara.

De kolonis a s a r s i p menggabungkan dua buah istilah, yaitu dekolonisasi dan arsip. Dekolonisasi arsip adalah sebuah proses, bukan hanya sekedar pengembalian arsip dari negara penjajah kepada negara terjajah. Dekolonisasi arsip membutuhkan praktik yang radikal (Ghaddar, 2019: 71). Arsip yang didekolonisasi mengacu pada jejakjejak material dan imaterial yang tak 
terhitung jumlahnya dan saling terkait. Dekolonisasi arsip akan melibatkan pihak yang pernah dikolonisasi dan pihak yang mengkolonisasi.

Dekolonisasi arsip berarti berfokus pada arsip kolonial. Seperti Jeurgens dan Karabinos (2020:--) berujar,

"decolonizing these archives is seeking ways to dismantle the hegemony of the custodial institutions in archival knowledge production and acknowledging that archival infrastructures are the key to agency"

"dekolonisasi arsip-arsip ini adalah mencari cara untuk membongkar hegemoni dari lembaga kustodial dalam penciptaan pengetahuan kearsipan dan mengakui bahwa infrastruktur kearsipan adalah kunci ke Lembaga tersebut"

Lebih jauh lagi, Jeurgens dan Karabinos mengungkapkan bahwa dekolonisasi arsip tidak serta merta hanya menyempitkan makna pada pemulangan arsip saja, tetapi juga pada prinsip-prinsip bagaimana arsip tersebut dikelola.

\section{PEMBAHASAN}

Penulis telah membahas sedikit mengenai teori dekolonisasi di bagian sebelumnya. Dekolonisasi tidak lepas dari dua pihak, atau bahkan lebih, yang terlibat. Satu pihak yang dikolonisasi dan satu pihak lainnya yang terkolonisasi. Dekolonisasi adalah sebuah proses yang terus berjalan. Ia tidak berhenti ketika pihak yang mengkolonisasi menyerahkan rampasannya ke pihak yang dikolonisasi.

Arsip telah lama dianggap sebagai sumber untuk menuliskan sejarah suatu bangsa. Penulisan sejarah bangsa ini nantinya akan membentuk suatu identitas daerah dan kemudian menjadi identitas nasional. Kisah asal usul suatu bangsa, sejarah, dan mitosnya, arsip berfungsi sebagai naskah penting untuk kewarganegaraan dan membimbing warga negaranya dalam memhami posisi mereka di dunia, dan siapa identitas mereka. Arsip membantu mereka untuk mengenal dan mengalami sendiri sebagai suatu bangsa tertentu, sejarah tertentu, dan wilayah tertentu. Studi ilmu kearsipan sudah barang tentu bukan barang baru lagi di dunia. Arsip dipandang sebagai pelacak jejak sejarah suatu bangsa, dan bahkan dianggap vital untuk pengembangan dan penyebaran konsep modern pembangunan bangsa.

Dekolonisasi arsip dimulai dari pengertian bahwa kolonialisme Barat, ras, dan kerajaan adalah dianggap sebagai aspek yang lebih luas daripada bidang kearsipan. Bidang-bidang tersebut terkait erat dengan semua segi tentang bagaimana manusia Barat berpikir, berbicara, dan bekerja di lapangan karena mereka mendefinikan fitur modernitas di manamana, termasuk dalam bentuk neoliberal 
sekarang.

Oleh karena itu, praktik arsip dekolonial bisa muncul dari berbagai segi proses dan struktur global, dan tertanam dalam diskursif yang lebih besar lagi, tempat banyak situs budaya, teks, dan konteks aktif. Hal ini memperhatikan koneksi yang kompleks antara arsip statis, khazanah, lembaga dan tradisi di satu sisi, dan sejarah, struktur modern suatu empire dan supremasi kulit putih di sisi lainnya.

Dekolonisasi arsip adalah suatu proses. Arsip yang berada di negeri yang dikolonisasi, masihlah arsip kolonial. Arsip tersebut masih mewarisi sistem recordkeeping kolonial. Tidak hanya bentuknya, isi dan sistemnya pun masih warisan kolonial. Lalu, sejauh mana dekolonisasi arsip yang terjadi sejauh ini? Apakah dekolonisasi arsip sudah dapat menurunkan makna kolonial di dalamnya? Dekolonisasi arsip yang terjadi adalah hanya pada pengembalian bentuk fisik arsip tersebut tanpa mengubah sistem dan struktur arsipnya.

Karabinos (2019) berpendapat bahwa untuk bisa mendekolonisasi arsip secara baik, kita harus bisa terlebih dahulu memiliki pengetahuan yang kuat mengenai asal-usul arsip tersebut. Asalusul itu meliputi sistem kearsipan zaman kolonial serta sistem informasinya. Untuk menyelami riset atau penelitian mengenai dekolonisasi arsip, kita harus bisa memahami bagaimana struktur administrasi pemerintah kolonial dan memproduksi knowledge atau ilmu pengetahuan.

Kaitan lain dekolonisasi dengan ilmu kearsipan adalah terletak pada aspek keadilan sosial. Aspek keadilan sosial ini meliputi dekolonisasi arsip di bidangbidang seperti memori, hak asasi manusia, identitas, keberagaman, dan pluralisme. Di aspek-aspek inilah mulai muncul pertanyaan di kalangan akademisi kearsipan seperti:

1. Bagaimana nantinya warisan kolonial (arsip) ini ditetapkan menjadi milik asalnya?

2. Bagaimana cara pengembalian arsip-arsip kolonial tersebut?

3. Bagaimana mempertahankan prinsip dasar kearsipan yaitu asalusul dan aturan asli bila arsip kolonial tersebut didekolonisasi?

\section{Dekolonisasi Arsip pada Era Digital}

Semakin berkembangnya teknologi, informasi, dan komunikasi di ranah kearsipan, berpengaruh juga pada dekolonisasi arsip. Era Revolusi Industri 4.0 yang menuntut kemudahan di segala aspek, termasuk kearsipan, membawa dampak perubahan di metode-metode dekolonisasi arsip.

Contoh paling nyata yang ada di hadapan kita misalnya, kita dengan sangat mudah menemukan arsip berisi tentang sejarah bangsa kita sendiri, tetapi berada di 
arsip negara lain. Salah satu wacana mengenai dekolonisasi arsip adalah melalui digitalisasi arsip. Alih-alih untuk memindahkan fisik arsip dari negara kolonialnya menuju negara asal arsip itu, opsi alih media arsip lebih banyak dipilih. Opsi tersebut dipilih karena lebih murah secara biaya, dan lebih rendah risikonya daripada memulangkan puluhan bahkan ratusan boks arsip.

Pertimbangan lain dekolonisasi arsip melalui metode alih media adalah akses arsip. Masyarakat pada era Revolusi Industri 4.0, tidak terlalu perduli dengan bagaimana arsip dirawat, diolah, dan kemudian disajikan menjadi layanan publik. Masyarakat berpikir menjadi lebih sederhana, yaitu asalkan mereka bisa mengakses arsip dari mana pun dan kapan pun. Digitalisasi arsip dipandang menjadi jalan yang paling feasible, atau yang paling memungkinkan untuk memudahkan akses arsip yang "didekolinasasi".

Namun, konsep digitalisasi juga bukan tidak ada yang menentang. Ada beberapa pendapat bahwa digitalisasi dapat merusak konteks arsip dan dapat bercampur dengan konteks yang lain. Bahkan, Jeurgens (2013) berpendapat bahwa digitalisasi dapat berpengaruh pada informasi yang tersusun dalam arsip tersebut.

Kelemahan lain dari digitalisasi arsip adalah masalah-masalah, seperti:
1. siapa yang akan mendanai digitalisasi secara masif?

2. siapa yang memutuskan arsip mana yang akan didigitalisasi?

3. arsip mana yang boleh diakses dan tidak?; dan

4. jika sudah didigitalisasi, siapa yang akan memiliki hasil digitalisasi tersebut?

Selain itu, masih banyak lagi pertanyaan yang muncul mengenai dekolonisasi arsip pada era digital ini. Arsip kolonial akan menjadi arsip kolonial yang didigitalisasi. Konteks dan informasi yang terstruktur di dalamnya tetaplah kolonial.

Dekolonisasi pada era digital juga menjadi pertanyaan ketika kemungkinankemungkinan mengakuisisi arsip yang telah dialihmediakan. Akuisisi ini melingkupi apakah benar yang akan diakuisisi keseluruhan khazanah yang telah digital? Ataukah hanya pada lembaran-lebaran yang terpisah antara satu konteks dengan konteks lainnya? Konsep dekolonisasi digital, semestinya lepas dari konteks kolonialisasi digital, seperti misalnya melibatkan banyak pihak untuk melakukan digitalisasi. Jika tidak, yang terjadi malah sebaliknya, yaitu kolonialisasi pada era digital.

\section{Arsip Hindia-Belanda yang Bisa Dilakukan Dekolonisasi}

Berbicara mengenai khazanah arsip, khususnya yang disimpan di ANRI, 
tidak terlepas mengenai periode asal arsip tersebut. Dari data khazanah yang ada di ruang baca ANRI, khazanah arsip dibagi menjadi beberapa periode, yaitu: periode VOC dan Hindia-Belanda, periode peralihan Inggris, dan periode Republik (setelah Indonesia merdeka). Periode Hindia-Belanda berada pada rentang tahun 1811-1949. Indonesia merdeka pada tahun 1945, tetapi arsip periode Hindia-Belanda masih bertahan hingga tahun 1949. Arsip ini bertahan karena pada rentang waktu 1945-1949, Belanda melakukan agresi militernya ke Indonesia.

Seperti telah disinggung oleh penulis di bab kerangka teori, bahwa pada hakikatnya, dekolonisasi melibatkan dua pihak, yaitu pihak yang dikolonisasi dan pihak yang mengkolonisasi. Dalam penelitian ini, penulis menganalisis khususnya arsip yang ada di ANRI yang periodenya masuk ke dalam periode Hindia-Belanda atau sering disebut periode kolonial. Arsip tersebut mencapai kurang lebih $10 \mathrm{~km}$ jumlahnya. Kebanyakan dari arsip tersebut medianya adalah kertas. Namun, ada juga media lain yaitu foto dan kartografi serta kearsitekturan.

Dalam laporan De Graaf (2013) mengenai kerja sama ANRI dengan Arsip Nasional Belanda (NA), kunjungan pertama delegasi NA terjadi pada tahun 1974. Kunjungan tersebut adalah tindak lanjut dari kerja sama kebudayaan antara
Indonesia dan Belanda. Dalam proyek ini, arsiparis NA mendata jumlah khazanah arsip Hindia-Belanda yang ada di Indonesia. Tujuannya adalah melakukan alih media dari arsip yang berbentuk kertas ke dalam bentuk mikro, salah satunya microfilm.

"Mijn uitzending naar Indonesië in
1974 was een direct gevolg ervan
hoewel de opdracht veel ruimer
werd opgevat door de toenmalig
Algemeen Rijksarchivaris: "kijk
maar eens hoe de zaken er daar
voor staan en in hoeverre we
kunnen samenwerken". Mijn
verzoek om een duidelijker
opdracht werd met een glimlach
beantwoord! Ik moest maar zien
en naar bevind van zaken
handelen. Een duidelijk oosters
getinte opdracht waarmee feitelijk
dearchiefsamenwerking begon."

"Pengutusan saya ke Indonesia tahun 1974 adalah akibat langsung meskipun penugasan tersebut ditafsirkan secara lebih luas oleh Arsiparis Negara pada waktu itu: 'lihat saja bagaimana keadaan di sana dan sejauh mana kita dapat bekerja sama'. Permintaan saya untuk tugas yang lebih jelas dijawab dengan senyuman! Saya hanya harus melihat dan bertindak sesuai dengan fakta. Tugas oriental yang jelas dimana kolaborasi arsip sebenarnya dimulai (De Graaf, 2013:7).”

Kerja sama ini bisa juga dilihat sebagai salah satu bentuk dekolonisasi, karena 
arsip yang dialihmediakan adalah khazanah ANRI dan NA yang kemudian ditukar dalam bentuk digital tersebut. Dalam perkembangannya, kerja sama ini terus berlanjut hingga sekarang, antara lain dalam bentuk pertukaran arsip, pameran, dan pengembangan sumber daya manusia (SDM).

Arsip periode Hindia-Belanda lainnya yang sudah dilakukan "dekolonisasi" adalah khazanah arsip Djogdja Documenten. Khazanah ini adalah arsip yang diciptakan pemerintah Indonesia ketika ibuota pindah ke Yogyakarta. Agen militer Indonesia yang dikenal dengan the Netherlands East Indies Forces Intelligence Services (NEFIS) merebut arsip tersebut pada tahun 1948. Kerja sama antara Indonesia dan Belanda akhirnya menyepakati untuk mengembalikan khazanah Djogdja Documenten tesebut.

Karabinos (2017) menyebutkan bahwa bukan tidak mungkin arsip Djogdja Documenten yang didekolonisasi pada tahun-tahun 1970-1990 masih ada yang tersisa dan juga ada arsip lain yang belum dikembalikan. Di Indonesia sendiri, khazanah arsip Djogdja Documenten hanya ada 356 nomor arsip. Karabinos menemukan sekitar 4.100 nomor arsip yang dikatakan direbut oleh NEFIS. Dari data ini, dapat dimungkinkan untuk mendekolonisasi kembali sisa arsip yang belum dikembalikan.
Selain arsip Djogdja Documenten, khazanah arsip lain yang mungkin juga bisa didekolonisasi adalah khazanah NEFIS sendiri yang masih sedikit terdapat di ANRI. Lebih lanjutnya, khazanah arsip Procureur-Generaal, atau kejaksaan tinggi, juga banyak disimpan di NA. Khazanah arsip tersebut menyimpan banyak informasi mengenai pergerakan tokoh-tokoh Indonesia pada era pergerakan, misalnya pengadilan terhadap Sukarno dan tokoh-tokoh lain. Khazanah ini juga banyak menyimpan album foto yang berisi tokoh-tokoh nasionalis Indonesia.

Banyak khazanah lain yang terpencar di dalam suatu inventaris khazanah arsip yang lebih besar yang disimpan di NA dan bisa dilakukan dekolonisasi. Misalnya, khazanah arsip Front Demokrasi Rakjat dan Kepolisian Negara. Di khazanah arsip Kementerian Pertahanan Belanda misalnya, tercecer juga banyak poster-poster kemerdekaan yang berhubungan langsung dengan perjuangan kemerdekaan Indonesia. Arsip-arsip tersebut bukan tidak mungkin bisa didekolonisasi.

\section{Kemungkinan Dekolonisasi Arsip Hindia-Belanda di Lingkungan Digital}

Penulis telah mengemukakan di bagian dekolonisai arsip secara digital bahwa untuk melakukan digitalisasi dibutuhkan banyak faktor. Sejauh 
pengamatan penulis, arsip Hindia-Belanda yang telah bisa dan mungkin didekolonisasi dan arsipnya sudah digital, adalah belum ada. Kecuali usaha untuk mengalihmediakan beberapa arsip dari khazanah Algemene Secretarie yang dalam bentuk mikro dihitung sebagai digitalisasi.

Kerja sama antara dua negara, yaitu Indonesia (yang diwakili ANRI) dan Belanda (yang diwakili NA) sudah memulai usaha untuk pertukaran arsip secara digital, yaitu dengan dilakukannya digitalisasi terhadap khazanah arsip Burgerlijke Openbare Werken (BOW), Algemene Secretarie, dan Java Noordooskust (Javanok). Digitalisasi ini dilakukan terhadap jalan masuk yang berupa indeks dari BOW dan Algemene Secretarie, juga terhadap arsip Javanok. Pertukaran arsip telah terjadi pada tahuntahun sebelumnya, yaitu Indonesia mendapatkan arsip-arsip pergerakan, dan juga arsip-arsip perbatasan. Di dalam kerja sama digitalisasi tersebut, juga terjadi transfer of knowledge (alih pengetahuan) mengenai kegiatan preservasi arsip statis. Sesuai dengan konsep dekolonsasi, alih pengetahuan juga terjadi dari Belanda ke Indonesia.

Dalam perkembangannya, kerja sama antara dua negara tersebut terus dikembangkan, dan diharapkan pertukaran arsip semakin banyak terjadi. Untuk menjawab tantangan pada pertanyaan ini, seperti:

1. siapa yang akan mendanai digitalisasi secara masif?;

2. siapa yang memutuskan arsip mana yang akan didigitalisasi?;

3. arsip mana yang boleh diakses dan tidak?; dan

4. jika sudah didigtalisasi, siapa yang akan memiliki hasil digitalisasi tersebut?

setidaknya sudah ada kasus-kasus yang mampu menjawabnya. Contoh kasusnya adalah pada digitalisasi arsip VOC ataupun digitalisasi yang dilakukan pada arsip Hindia-Belanda.

Jawaban-jawaban dari pertanyaan tersebut adalah:

1. Siapa yang akan mendanai digitalisasi secara masif?

Pada contoh kasus di digitalisasi arsip VOC dan Hindia-Belanda, kedua negara terkait (Indonesia dan Belanda) turut berkontribusi terhadapa pendanaan. Untuk alatalat dan biaya SDM, maka pihak Belanda yang membiayai, sedangkan untuk fasilitas ruangan dan kelengkapan umum seperti sarana listrik, air, dll, pihak Indonesia yang bertanggung jawab.

2. Siapa yang memutuskan arsip mana yang akan didigitalisasi?

Untuk menentukan arsip mana yang akan didigitalisasi, 
diperlukan rapat di antara kedua pihak, antara Indonesia dan Belanda. Keputusan mengenai ini agak lama dan sukar karena keduanya memiliki kepentingan yang sama menguntungkan untuk kedua negara. Aspek-aspek dalam memutuskan, biasanya terletak pada ada tidaknya suatu khazanah di negara bekas jajahan. Maka, konsep dekolonisasi bisa terjadi. Misalnya, di Indonesia tidak memiliki atau hanya sedikit memiliki arsip mengenai pergerakan perjuangan kemerdekaan Indonesia, maka Indonesia meminta Belanda untuk melakukan digitalisasi terhadap arsip yang terkait perjuangan kemerdekaan Indonesia. Diskusi pun akan berlanjut, apakah Belanda bersedia atau tidak. Jika bersedia, Belanda mengajukan j u g a proposa 1 un t u k mendigitalisasi khazanah arsip yang memang mereka tidak punya. Maka, keputusan mengenai khazanah ini terbilang lama.

3. Arsip mana yang boleh diakses dan tidak?

Untuk masalah akses, biasanya kedua negara mengacu pada Undang-undang keterbukaan publik. Di Indonesia mengacu kepada Undang-Undang tentang
Keterbukaan Informasi Publik (KIP), dan di Belanda mengacu kepada Openbaarheidswet.

4. Jika sudah didigitalisasi, siapa yang akan memiliki hasil digitalisasi tersebut?

Untuk masalah hak, ini juga menjadi pembicaraan yang alot, sejauh apa pengertian hak tersebut. Apakah hanya sekedar hak milik, hak cipta, atau juga termasuk hak diseminasi melalui portal khusus atau semacamnya. Biasanya, untuk hak kepemilikan, hasil digitalisasi menjadi hak negara yang terkolonisasi, dan negara kolonial mendapatkan hak diseminasi. Contohnya pada kasus digitalisasi arsip Hindia-Belanda, ANRI berhak menyimpan hasil digitalisasinya yang berupa file master dan juga file akses, namun NA hanya berhak menyimpan kopi digitalnya dan hanya bisa dilayankan di ruang baca NA.

\section{KESIMPULAN}

Dekolonisasi merupakan sebuah proses yang terus belangsung dan tidak dapat dilakukan secara cepat. Dekolonisasi arsip juga demikian. Dekolonisasi arsip tidak dapat dilepaskan dari dua pihak yang terlibat, yaitu negara yang mengkolonisasi dan negara yang dikolonisasi. Proses mengidentifikasi 
khazanah dapat berlangsung lama, bahkan contoh pengembalian arsip Djogdja Documenten yang memakan waktu dari tahun 1970-1990. Selain proses identifikasi, teknis untuk pengembalian khazanah arsip juga akan memakan waktu bila yang diinginan adalah arsip konvensional. Pertimbangan sarana angkut dan pemilihan rute juga menjadi hal-hal yang lama untuk direncanakan dan dipertimbangkan.

Dari kasus-kasus yang sudah pernah terjadi, dekolonisasi bisa dilakukan baik di lingkungan konvensional (analog) maupun lingkungan digital. Di lingkungan konvensional, kendala yang akan dihadapi adalah waktu untuk memindahkan fisik arsip dari satu negara ke negara lainnya. Faktor keamanan akan fisik arsip juga sangat berpengaruh. Di lingkungan digital, beberapa faktor yang harus dilihat untuk mendekolonisasi antara lain faktor pendanaan dan juga kesiapan negara yang melakukan dekolonisasi arsip. Selain hal teknis seperti pendanaan dan kesiapan negara, masalah hak-hak intelektual seperti hak cipta juga menjadi faktor yang akan muncul ketika dekolonisasi dilakukan di lingkungan digital. Belum lagi masalahmasalah alih ilmu pengetahuan yang menyertai arsip yang didekolonisasi.

Kajian awal tentang dekolonisasi arsip statis era Hindia-Belanda ini masih sangat terbatas pada ketersediaan kasuskasus yang sudah pernah terjadi dan juga ketersediaan informasi lanjutan mengenai kerja sama yang telah dilakukan. Penelitian ini masih sangat terbuka lebar untuk penelitian lanjutan, misalnya untuk kembali mengidentifikasi khazanah arsip yang dapat didekolonisasi.

\section{DAFTAR PUSTAKA \\ Sumber Bahan Pustaka}

Appadurai, Arjun. (1996). Modernity At Large: Cultural Dimensions of Globalization. Minneapolis: University of Minnesota Press.

Fanon, Frantz. (1963). The Wretched of the Earth. New York: Grove Weidenfeld A division of Grove Press.

Ghaddar, JJ dan Michelle Caswell. (2019). "To Go Beyond": Towards a Decolonial Archival Praxis. Archival Science, 19:71-85.

Graaff, M.G.H.A de. (2013). Archiefssamenwerking tussen Indonesie and Nederland. Den Haag: Nationaal Archief.

Jeurgens, K.J.P.F.M. (2013). The Scent of the Digital Archive. Dilemmas with Archive Digitization. BMGN Low Countries Hist Rev 128:30-54.

dan Michael Karabinos. (2020). Paradoxes of Curating Colonial Memory dalam Archival Science, Issue 1 March 2020. Switzerland: Springer Nature.

Karabinos, Michael. (2018). Decolonisation in Dutch 
Archives Defining and Debating. BMGN-Low Countries Historical Review, 134(2), 129-141.

(2017). Indonesian National Revolution Records in the National Archives of he Netherlands. Displaced Archives. London: Taylor and Francis Group.

Kennedy, Dane. (2016). Decolonization: a Very Short Introduction. Oxford: Oxford University Press.

Mbembe, Achille. (2015). Decolonizing Knowledge and the Question of the Archive. Public lectures given at the Wits Institute for Social and Economic Research (WISER), University of the Witwatersrand (Johannesburg).

Mir, Farina. (2015). AHR Roundtable: The Archives of Decolonization, Introduvtion dalam The American Historical Review, Volume , 120(3), 844-851. Oxford: Oxford University Press.

Mudzakir, Amin. (2015). Dekolonisasi Sejarah Indonesia dalam Perspektif Poskolonial Belanda. The Third Graduate Seminar of History. Universitas Gadjah Mada, Yogyakarta. 3-4 November 2015.

Risam, Roopika. (2018). Decolonizing Digital Humanities in Theory and Practice. English Faculty Publications. Salem State University.
Smith, Linda Tuhiwai. (2007). Decolonizing Methodologies: Research and Indigenous People. New York: Zed Books.

\section{Sumber Produk Hukum}

Undang-Undang Nomor 43 Tahun 2009 tentang Kearsipan, Jakarta.

Vienna Convention on Succession of States in respect of State Property, Archives and Debts 1983. 